\title{
ASSESSMENT OF THE IMPACT OF MODIFIER AND FILLER ON THE RHEOLOGICAL AND PHYSICAL AND MECHANICAL PROPERTIES OF PLASTER SOLUTIONS
}

\author{
${ }^{1}$ Savchenko S.V., PhD., Assistant Professor, \\ koval_sv@ukr.net, ORCID: 0000-0002-4973-0552 \\ ${ }^{1}$ Antoniuk N.R., Ph.D., Associate Professor, \\ antonuk_nr@ukr.net, ORCID: 0000-0003-1730-0723 \\ ${ }^{1}$ Bachynckyi V.V., Ph.D., Senior Research Fellow \\ slawa_dk@ukr.net, ORCID: 0000-0003-2187-8616 \\ ${ }^{1}$ Odessa State Academy of Civil Engineering and Architecture \\ 4, Didrichson street, Odessa, 65029, Ukraine
}

\begin{abstract}
The possibility of using microsilica as a filler for cement plaster mortars was analyzed. As a result of the analysis of reference data, the features of the hydration of cement with microsilica were determined. In the experiments, the rheological characteristics of cement slurries containing microsilica with different contents of amorphous silica and specific surface area were studied.

One of the most important objects of studying the effect of microsilica and superplasticizer additives on the properties of plaster solutions was optimization due to the optimal selection of the concentrations of additives, the rheological properties of mixtures and their ratio with technological and operational factors.

For the analysis and optimization, the quantitative ratio between the indicators of the structure and properties of plaster solutions and their determining factors, the formulations and technologies were obtained in the form of experimental-statistical models calculated using the COMPEX system.

Based on the results of measurements of the rheological properties of cement solutions containing silica fume with the highest specific surface area and $\mathrm{SiO}_{2}$ content, complete rheological curves "strain rate - stress" were constructed and models of the main rheological parameters were calculated.

To analyze the possibility of regulating the properties of cement systems with a superplasticizer, depending on the grain and chemical composition of the ultradispersed filler, multicomponent tetrahedral diagrams, which were combined with the concentration space of $\mathrm{D}_{\mathrm{SP}}-\mathrm{D}_{\mathrm{MC}}$ in the "mixture technology - properties" models were used.

A specially synthesized saturated plan of 21 points has been implemented. Models were obtained in the form of reduced polynomials for different properties of cement-sand mortars (mobility and compressive strength after 1,3, 9, 28 and 81 days of hardening in normal humidity conditions). Using a generalizing indicator, the sensitivity of the system to fluctuations in the fractional composition and $\mathrm{SiO}_{2}$ content was estimated.
\end{abstract}

Keywords: plaster mortar, microsilica, superplasticizer, rheological properties, strength.

Introduction. Modern plaster mortars are multicomponent systems that include multifunctional modifiers with multidirectional action and various types of fillers, which improve both the physical and mechanical properties of mortars and their performance while reducing production costs. As a filler, ultradispersed waste from ferroalloy industries was used, a distinctive feature of which is a highly developed specific surface area on average $3500 \mathrm{~cm}^{2} / \mathrm{g}$ and a high content of silicon dioxide or amorphous silica up to $95 \%$. The specific surface area of microsilica (MC) leads to an increase in the water demand of solutions, which can be leveled by the introduction of a superplasticizer (SP).

Analysis of recent research and publications. The mechanism of action of microsilica is that in the presence of microsilica from the liquid phase contained in the pores of the hardening solution, there is a partial removal of hydroxyl ions and alkali metal ions, which reduces the rate of reaction between alkalis and silica. The resulting gel of hydrated calcium silicate, sodium and potassium slowly adsorbs moisture [1]. As a result, the expansion of solutions containing up to 15-20\% MC decreases and slows down in time. The introduction of small proportioning of MK (up to 5\%) leads to an increase in the expansion of solutions [2]. 
As a result of the analysis of reference data [3-5], the features of the hydration of cement with microsilica were determined:

- with an increase in the proportion of MC (up to 20\%), the amount of chemically bound water in cement with $\mathrm{MC}$ in the initial period are practically the same as in the non-additive cement composition, however, on the 28th day, the water absorption becomes $1.5 \%$ more, despite the fact that cement contains $20 \%$ less than in a non-additive composition;

- the process of cement hydration with the addition of MC proceeds and the release of more heat than that of the non-additive composition, and the extremum shifts to the region from 10 to 20 hours. The position and amplitude of the peak depends on the proportionment of the plasticizer;

- the pozzolan reaction of cement with microsilica is characterized by a high initial reaction rate, the absolute value and direction of which differ significantly from the corresponding values of fly ash.

In foreign sources there is information that the grain of MC is 100 times smaller than the grain of cement $[2,4]$, or one grain of cement accounts for 50-100 thousand grains of microsilica. Silica of this size is referred to as colloidal.

Due to the significant ability to aggregate and structure formation, the mineral filler is able to form cluster structures [6,7] and to capture into the volumetric excess amount of the liquid phase [3]. Thus, there is evidence that with the introduction of silica fume around the binder particles, relatively thin (1-2 $\mu \mathrm{m}$ thick) films of water are formed than when mixing conventional cements [4, 5]. Aggregates containing free water in their cells are retained during vibration, which reduces segregation of cement systems.

The introduction of microsilica noticeably reduces the mobility of cement systems, increases the connectivity, sharply decreases delamination and water separation. A significant decrease in the number of water separation channels due to the use of $\mathrm{MC}$, contributes to reduce stratification and improve the rheological characteristics of cement systems, as well as the physical and mechanical characteristics of composites based on them [8].

There are three main directions of using MC in the technology of preparing plaster mixes:

- quality management of plaster solutions;

- reducing the resource intensity of plastering compounds;

- improved operating characteristics.

The developed specific surface area of microsilica contributes to a sharp increase in the concentration of the dispersed phase, which leads to an increase in the water demand of the mixtures and deterioration of the rheological properties. However, the use of plasticizing additives makes it possible to compensate for this negative effect, improve not only rheological parameters, but also create favorable conditions for the structure formation and hydration of cement stone [8].

The purpose of this research is to determine the optimal concentrations of microsilica and superplasticizer to improve the rheological and physical-mechanical properties of plaster solutions, as well as to assess the sensitivity of the system to changes in the mineralogical and chemical compositions of microsilica.

Objects and methods of research. In the experiments, no additives Portland cement with an activity of $375 \mathrm{~kg} / \mathrm{cm}^{2}$ of the Olshansk plant was used as a binder. River sand with $\mathrm{M}_{\mathrm{cr}}=2.1$ was used as a fine aggregate, which agreeable to the standards for plaster solutions. Superplasticizer S-3 was used as a plasticizer.

The preparation of cement mortars was carried out using a mixer. Determination of the setting time was carried out using a standard method. To determine the rheological characteristics were used: Weiler-Rebinder device, technical viscometer "Polymer" RPE-1M and a modified plastometer.

For the analysis and optimization, the quantitative ratio between the indicators of the structure and properties of plaster solutions and the determining factors of the formulation and technology in the form of experimental statistical models (ES models) which calculated using the COMPEX system were obtained.

In all experiments, the lower level of varying the proportioning of the superplasticizer and ultradispersed filler $\mathrm{x}_{1}=\mathrm{x}_{2}=-1$ was combined with zero concentration, which allows one model to research composites: reference $\left(\mathrm{x}_{1}=\mathrm{x}_{2}=-1\right)$; with superplasticizer $\left(-1 \leq \mathrm{x}_{1} \leq+1, \mathrm{x}_{2}=-1\right)$; with

Bulletin of Odessa State Academy of Civil Engineering and Architecture, 2021, no. 82, page 105-113 
microsilica $\left(-1 \leq \mathrm{x}_{2} \leq+1, \mathrm{x}_{1}=-1\right)$.

In the experiments, the rheological characteristics of cement pastes containing microsilica and differing in the content of amorphous silica and specific surface area were investigated: $\omega_{1}-$ $\mathrm{SiO}_{2}=70 \%, \mathrm{~S}_{\mathrm{sp}}=44 \mathrm{~m}^{2} / \mathrm{g} ; \omega^{2}-\mathrm{SiO}_{2}=90 \%, \mathrm{~S}_{\mathrm{sp}}=20 \mathrm{~m}^{2} / \mathrm{g} ; \omega_{3}-\mathrm{SiO}_{2}=83 \%, \mathrm{~S}_{\mathrm{sp}}=24 \mathrm{~m}^{2} / \mathrm{g}$ and $\omega_{4}-$ $\mathrm{SiO}_{2}=75 \%, \mathrm{~S}_{\mathrm{sp}}=33 \mathrm{~m}^{2} / \mathrm{g}$.

The results of research. The values of the effective viscosity $\eta(\mathrm{Pa} \cdot \mathrm{s})$, obtained at constant deformation $\left(\dot{\varepsilon}=\right.$ const $\left.=1 \mathrm{~s}^{-1}\right)$ (shown in Fig. 1, a), served as a compared characteristic of the surface activity of fillers. They integrally characterize the structure-forming ability of fillers (due to adsorption, chemical bonds) [9-13]. All other things being equal, the viscosity increases most rapidly with an increase in the microsilica concentration $\omega_{1}$ in the absence of a superplasticizer. The viscosity index increased according to the given sequence (the index "c" indicates the presence of a superplasticizer): $\omega_{2}{ }^{\mathrm{c}}-\omega_{3}{ }^{\mathrm{c}}-\omega_{4}{ }^{\mathrm{c}}-\omega_{1}{ }^{\mathrm{c}}$.

For cement pastes with microsilica $\omega_{1}$, the viscosity increases sharply with increasing proportioning from 0 to $15 \%$, however, with the introduction of $0.4 \%$ of superplasticizer $\mathrm{S}-3$, the effective proportioning of microsilica can be increased by $5 \ldots 7 \%$ without increasing $\eta$. It is known [14] that the introduction of surfactants results in the separation of a part of the immobilized water and a decrease in the aggregate stability of the system. Water demand depends on dispersion and increases with an increase in specific surface area. An exception is the sample with $\omega_{2}$, the viscosity of which can be compared with the viscosity of the non-additive composition. This may be associated with an increased content of hydrophilic components $\mathrm{Cr}_{2} \mathrm{O}_{3}$ and $\mathrm{Al}_{2} \mathrm{O}_{3}$ in $\omega_{2}$ [15], but, first of all, with a lower specific surface area of particles.

In Fig. 1, b shows plastograms obtained with the same water-binding ratio of cement pastes. Plastograms clearly show two periods in the process of structure formation. The first - the period of structure formation - is characterized by the predominance of a coagulation structure with thixotropic reversible properties; the second - the hardening period - characterized by the predominance of the crystallization-coagulation structure with the properties of an elastic-brittle body (according to P.A.Rebinder).

a)

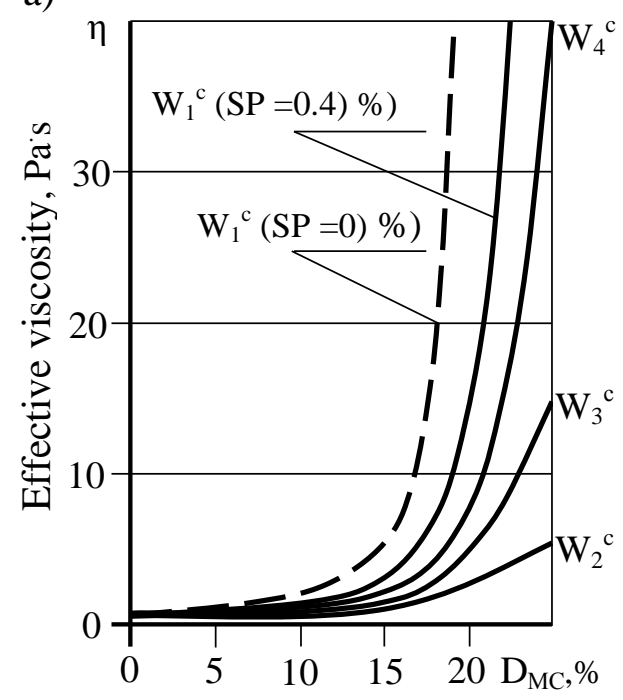

b)

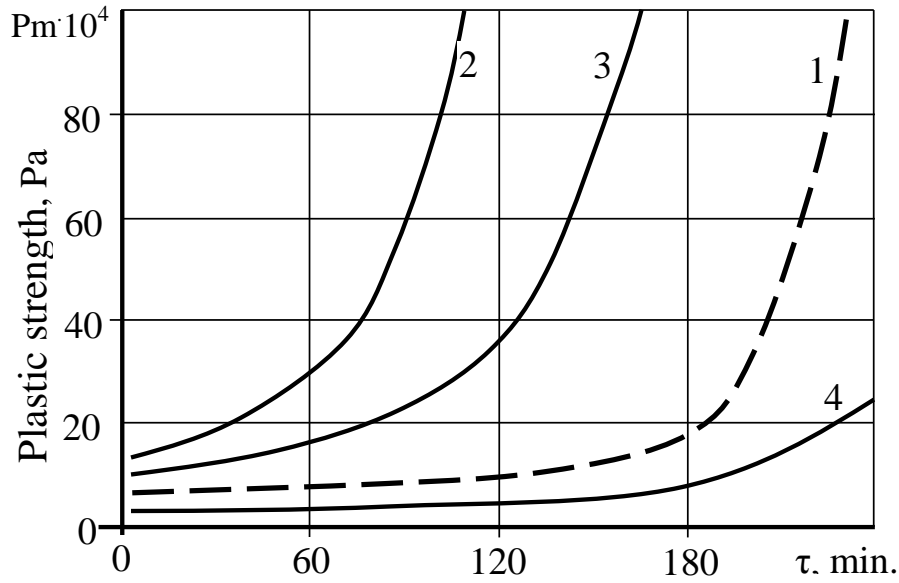

$1-$ standard; $2-\mathrm{MC}=10 \% ; 3-10 \% \mathrm{MC}+0,4 \% \mathrm{SP} ; 4-\mathrm{SP}=0,4 \%$

Fig. 1. Change in rheological parameters of cement pastes:

a - effective viscosity $\eta$ with the introduction of various microsilica $\omega_{1}-\omega_{4}$;

$\mathrm{b}$ - plastic strength $\mathrm{P}_{\mathrm{m}}$

Based on the results of measurements of the rheological properties of cement pastes containing microsilica $\omega_{1}$ with the highest specific surface area, carried out using a Weiler-Rebinder device, complete rheological curves "strain rate - stress" were constructed and models of the main rheological parameters were calculated, in particular, the ultimate shear stress $\tau_{0}(\mathrm{~Pa})$ : 


$$
\begin{array}{rll}
\tau_{0}=140.1-1.1 \mathrm{x}_{1}+1.9 \mathrm{x}_{1}^{2}-1.6 \mathrm{x}_{1} \mathrm{x}_{2} & +1.8 \mathrm{x}_{1}{ }^{2} \mathrm{x}_{2} \\
-1.1 \mathrm{x}_{2}-1.1 \mathrm{x}_{2}{ }^{2} & -1.8 \mathrm{x}_{1} \mathrm{x}_{2}^{2}
\end{array}
$$

In Fig. 2 shows nomograms for ultimate shear stress $\left(\tau_{0}\right)$, dynamic elastic modulus $(\mathrm{G})$, and relaxation period $\left(\mathrm{n}_{1}\right)$. In Fig. 2, a shows the change in the value of $\tau_{0}$ for various compositions with the addition of $\mathrm{MC}+\mathrm{SP}$ at a constant water content equal to that of the reference composition. The analysis shows that with the transition from the additive-free composition to the compositions with high proportioning of MC and SP, the ultimate shear stress will decrease, i.e. such mixtures will be better processed. With an increase in the MC proportioning from 0 to $40 \%$, the indicator increases by 3-4 times and decreases by 1.5-2 times during using a superplasticizer.

a)

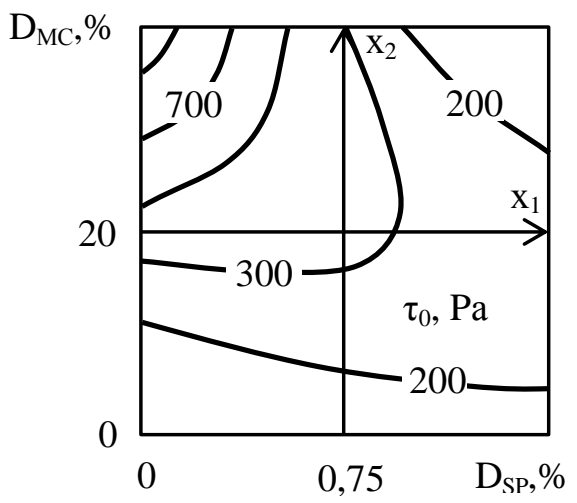

b)

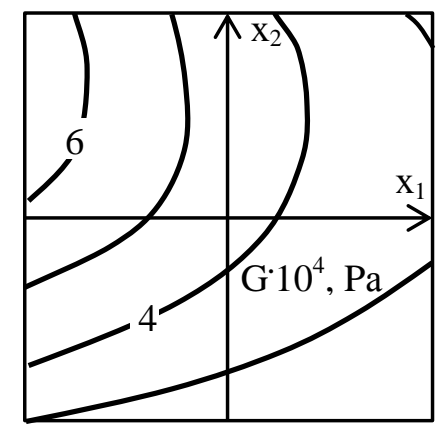

c)

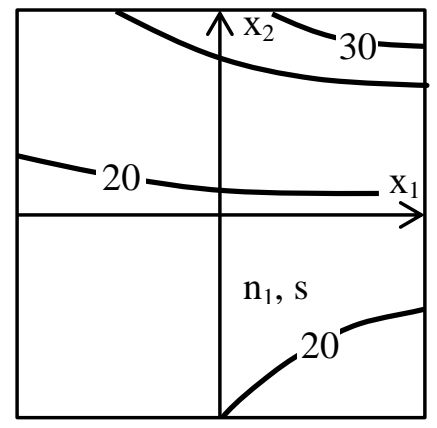

Fig. 2. Change in rheological parameters:

$\mathrm{a}$ - limiting shear stress $\tau_{0} ; \mathrm{b}$ - dynamic modulus of elasticity $\mathrm{G} ; \mathrm{c}$ - relaxation period $\mathrm{n}_{1}$

In the factor space of $\mathrm{D}_{\mathrm{MC}}-\mathrm{D}_{\mathrm{SP}}$, there are areas in which the rheological parameters of cement pastes, including $\tau_{0}, \mathrm{G}$ and $\mathrm{n}_{1}$ (Fig. 2, a-c), with the addition of $\mathrm{MC}+\mathrm{SP}$ are close to the rheological parameters of the non-additive composition.

The conclusion about the existence of such "isorheological" regions was confirmed by the analysis of models of various indicators, including viscosity $\eta$ and plastic strength Pm.

To maintain the condition of "isorheology" of mixtures, for every $5 \% \mathrm{MC}$, the concentration of SP should be increased by $0.16-0.20 \%$. In the technological aspect, the existence of areas of "isorheological" formulations made it possible to draw a conclusion about the possibility of using ultradispersed filler in plaster solutions.

To analyze the possibility of regulating the properties of cement systems with SP, depending on the grain and chemical composition of the ultradispersed filler, multicomponent tetrahedral diagrams were used [16], which were combined with the concentration space of $D_{M C}-D_{S P}$ in the "mixture technology - properties" models. The vertices $\omega_{1} \ldots \omega_{4}$ of the mixed tetrahedron (Fig. 3, b) characterize four types of MCs (differing, first of all, in the specific surface area and the content of amorphous silica).

The mutually independent variables corresponded to: $x_{1}=D_{S P}=0.45 \pm 0.45 \%$ - concentration, by weight of cement, superplasticizer S-3 and $\mathrm{x}_{2}=\mathrm{D}_{\mathrm{MC}}=10 \pm 10 \%$ - concentration of fillers in cement.

A specially synthesized full experiment plan of 21 points has been implemented. For different properties of cement-sand mortars (mobility and compressive strength after 1, 3, 9, 28 and 81 days of hardening in normal humidity conditions), the models are obtained in the form of reduced value. Strength model $\mathrm{R}_{\mathrm{c}}{ }^{28}(\mathrm{MPa})$, displayed on the diagram "triangles on a square" (Fig. 3) has the form:

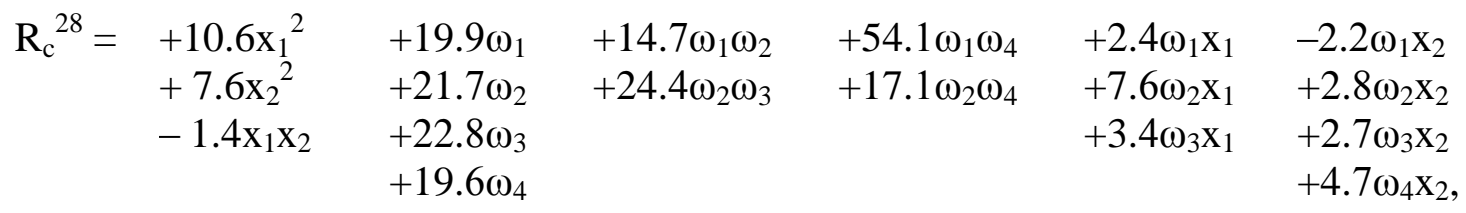


a)
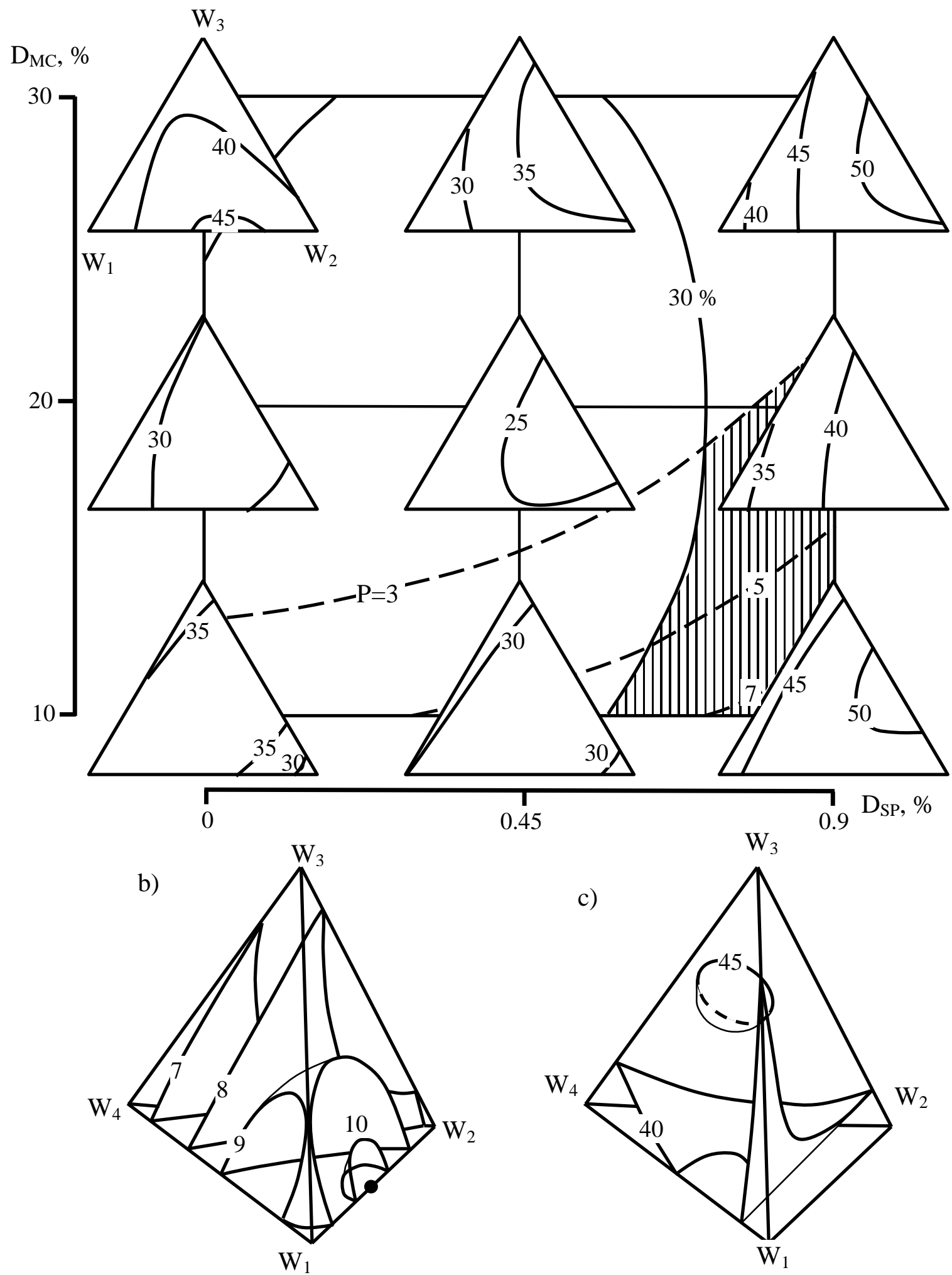

Fig. 3. Selection of the recipe area for optimal compositions:

$\mathrm{a}$ - nine three-component granulometric diagrams for the strength $\mathrm{R}_{\mathrm{c}}{ }^{28}$ of cement-sand mortars, built on the bearing square "MC concentration - SP concentration" with the selection of the area of optimal solutions (hatching); $\mathrm{b}$ - four-component diagram $\mathrm{R}_{\mathrm{c}}{ }^{3}$; $\mathrm{c}-\operatorname{diagram} \mathrm{R}_{\mathrm{c}}{ }^{81}$

The nature of the effect of fillers depends on the concentration of $\mathrm{D}_{\mathrm{MC}}$ and particle board. The maximum possible strength is achieved by adding SP for mixtures of fillers $\omega_{1}+\omega_{2}$. The optimum strength changes over time: if the maximum strength for 1 day was provided by a filler consisting of 
a mixture of $\omega_{1}$ and $\omega_{2}$ (a four-component diagram with $\mathrm{D}_{\mathrm{SP}}=0.9 \%, \mathrm{D}_{\mathrm{MC}}=10 \%$ was shown in Fig. 3, b), then at the age of 81 days the maximum strength moves towards the three-component mixture $\omega_{2}+\omega_{3}+\omega_{4}$.

When combining the isolines of the mobility of the mixture P> $3 \mathrm{~cm}$ (hatching lines in Fig. 3, a) and the isolines of the efficiency indicator (determined as a percentage as the area on the threecomponent diagram of the region $\mathrm{R}^{\mathrm{S}} \geq 35 \mathrm{MPa}$ ), the optimal proportioning of microsilica and superplasticizer were identified, which are effective for plaster solutions (hatching area in Fig. 3, a). Without the use of a superplasticizer, technologically acceptable compositions with microsilica cannot be obtained at all; the best are two-component mixtures $\omega_{2}+\omega_{3}$ - containing an increased $\mathrm{SiO}_{2}$ as compared to other fillers.

The change in strength over time of cement compositions containing filler $\omega_{1}$ (maximum $S_{\mathrm{sp}}$ ) and filler $\omega_{2}$ (maximum $\left.\mathrm{SiO}_{2}\right)$ is shown in Fig. 4, b, where: $\mathrm{I}$ - change in plastic strength $\mathrm{Pm}(\tau=60 \mathrm{~min}$.), II-VI - change in compressive strength, respectively, at 1, 3, 9, 28 and 81 days of hardening in normal humidity conditions. Their comparison shows that in the early period of hardening the samples with microsilica $\omega_{1}$ are characterized by higher strength than samples with microsilica $\omega_{2}$ and reference samples. However, after 3 days of hardening, the nature of the effect on the strength of microsilica changes: a greater increase in strength is associated with a filler with a high content of $\mathrm{SiO}_{2}$. At all times of hardening, the strength of modified cement compositions is higher than the strength of no-additives.

The sensitivity of the system to fluctuations in the fractional composition and content of $\mathrm{SiO}_{2}$ was characterized by the models of the generalizing indicator $æ:$

$$
æ=\mathrm{R}\{\mathrm{MK}\}: \mathrm{R}\{\mathrm{MK}=0\}, \%
$$

In Fig. 4. the sensitivity of the system was analyzed with respect to the non-additive composition (indicated by the hatching line). For various fillers, the $æ$ index can differ by more than two times, which is associated with a time change in the structure-forming role of $\mathrm{S}_{\mathrm{sp}}$ and $\mathrm{SiO}_{2}$ (Fig. 4, b). So, if the optimal strength in the initial period (1-3 days) is a single-fraction filler $\omega_{1}$ with a maximum specific surface area, then in a later period (28 days) the maximum solution strength was provided by a two-fraction filler with an increased $\mathrm{SiO}_{2}$ content at ratios $\omega_{2}=65$ and $\omega_{3}=35 \%$, and at the age of 81 days. The maximum strength was associated only with microsilica, which has an increased content of $\mathrm{SiO}_{2}\left(\omega_{2}\right)$ - the role of the specific surface is leveled.

Conclusions and prospects for further research. The research of the rheological properties of modified cement systems showed that the structure-forming effect of the ultradispersed filler, as a rule, is of a positive direction, but its introduction changes the rheological characteristics of the mixtures (viscosity, plastic strength, etc.) and this can be compensated by the introduction of a superplasticizer. The optimal ratio of MC and SP allows reducing the ultimate shear stress and viscosity with an increase in the rate of structure formation (up to 2 times). To preserve the condition of "isorheology" of mixtures for every 5\% of MC, the concentration of SP should be increased by $0.16 \ldots 0.20 \%$. The effectiveness of using MC for plaster mortar was indicated by the fact of a decrease in the elastic modulus, as well as the possibility of controlling the viscosity of the mixtures and the ultimate shear stress - important technological characteristics.

After analyzing the changes in the properties of the multicomponent system, it was noted that the nature of the action of fillers and the optimal granulometry of the filler depend on the concentration of the superplasticizer and microfiller, along with this the optimum strength of cement-sand mortars changes over time. At all times of hardening, the strength of modified cement compositions is higher than the strength of no-additives. It was also noted that for various fillers, the indicator characterizing the sensitivity of the system to fluctuations in the fractional composition and $\mathrm{SiO}_{2}$ content may differ by more than 2 times. Generalization of the models describing the properties of a multicomponent system made it possible to hypothesize that the structure-forming role of $\mathrm{SiO}_{2}$ factors and specific surface area $S_{\mathrm{sp}}$ changes in time and, depending on the concentration of the superplasticizer.

In further researches, it is advisable to analyze the influence of the optimal ratios of the concentration of superplasticizer and microsilica on the operational properties of plaster solutions. 
a)
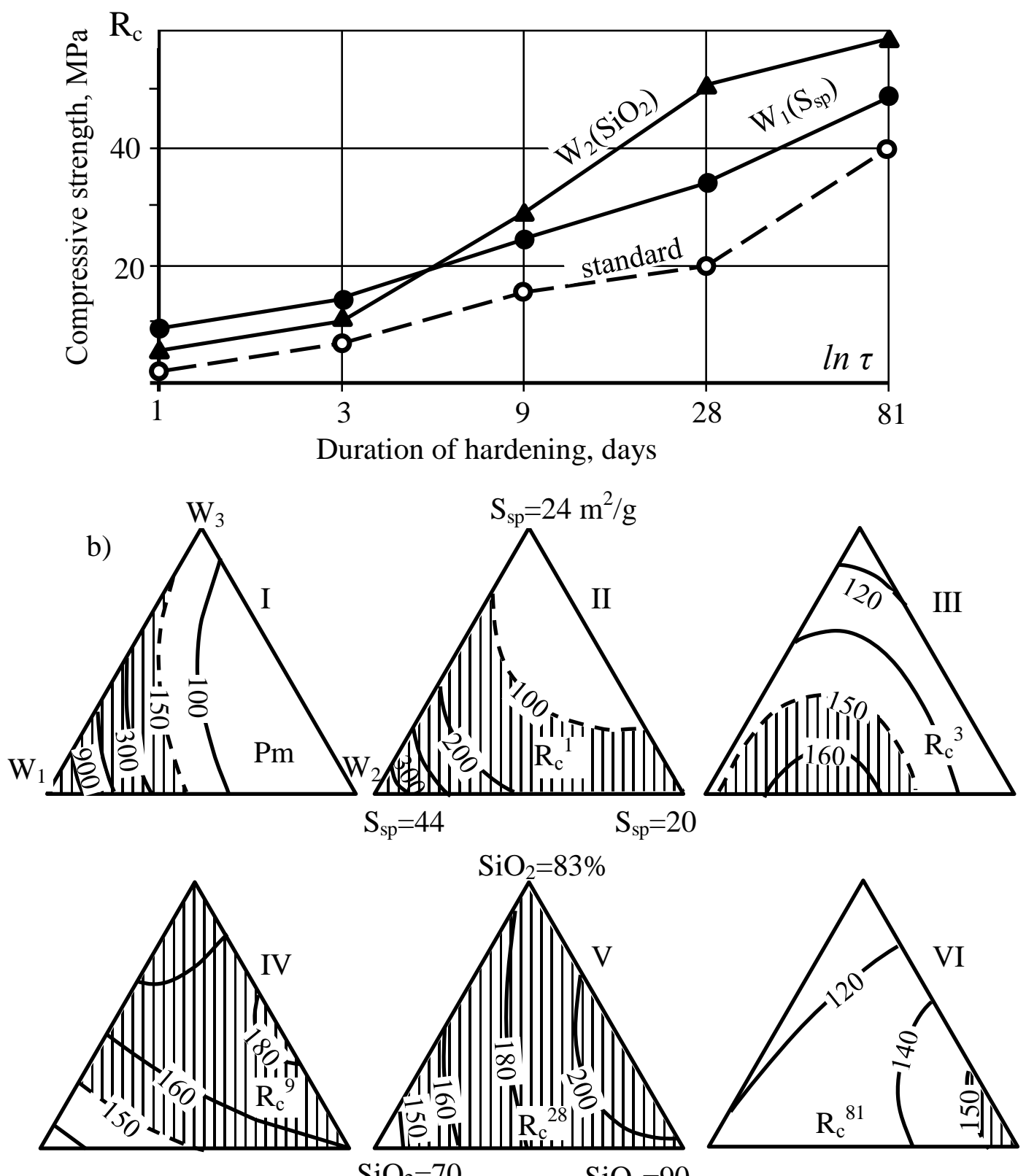

$\mathrm{SiO}_{2}=70$

$\mathrm{SiO}_{2}=90$

Fig. 4. Influence of the type of microsilica on the strength of cement compositions: $\mathrm{a}$ - the kinetics of change in strength by using two fillers $\mathrm{W}_{1}$ and $\mathrm{W}_{2} ; \mathrm{b}$ - change in the efficiency of fillers during hardening $\left(\mathfrak{x}=\mathrm{R}_{\mathrm{MC}}: \mathrm{R}_{\mathrm{EH}}\right)$

\section{References}

[1] M.D. Cohen, V. Klisikas, "Meshanisms of hidration and strength develjpments in Portland cement composites containing silica fume particles", Ind. Concrete J., vol. 60, no. 11, pp. 296-300, 1986.

[2] A. Dhagat, M. Mittal, "Effect of Microsilica and fly ash on the strength of concrete", IJSER, Vol. 4, Issue 8, pp. 1399-1402, 2013.

[3] O.A. Moskalenko, "Doslidzhennya vplyvu orhano-mineral'noho kompleksu vyrobnytstva TOV «MTS Baukhemi» na fizyko-mekhanichni vlastyvosti shlakovmishchuyuchykh tsementiv", Visnyk Odes'koyi derzhavnoyi akademiyi budivnytstva ta arkhitektury, vol. 80, pp. 75-83, 2020. https://doi: 10.31650/2415-377X-2020-80-75-83.

[4] K.K. Pushkarova, K.O. Kaverin, D.O. Kalantaevsky, "Vpliv organo-mineralnih dobavok na reologichni vlastivosti cementnih kompozicij ta yihni fiziko-mehanichni harakteristiki", $Z b$. nauk. pr. Ukrayinskogo derzh. un-tu zaliznichnogo transportu, vol. 155, pp. 124-128, 2015. 
[5] K.K. Pushkarova, K.O. Kaverin, D.O. Kalantaevsky, "Research of high-strength cement compositions modified by complex organic-silica additives", Eastern-European Journal of Enterprise Technologies, vol. 5, Iss. 5 (77), pp. 42-51, 2015. https://doi: 10.15587/17294061.2015.51836.

[6] V.M. Vyirovoy, O.O. Korobko, V.G. Suhanov, N.V. Kazmirchuk, S.S. Makarova. Strukturoutvorennya ta rujnuvannya budivelnih kompozitiv: navch. posib. Odesa: ODABA, 2020.

[7] V.G. Suhanov, V.N. Vyirovoy, O.A. Korobko, Struktura materiala v strukture konstruktsii. Odessa : POLIGRAF, 2016.

[8] S. Kroviakov, A. Mishutin, O. Pishev, "Management of the properties of shipbuilding expanded clay lightweight concrete", International Journal of Engineering \& Technology, vol. 7, no. 3.2, pp.245-249, 2018. https://doi: 10.14419/ijet.v7i3.2.14412.

[9] L.J. Dvorkin, O.L. Dvorkin, Osnovi betonoznavstva. Kiev.: Osnova, 2007.

[10] R.F. Runova, Yu.L. Nosovskij, Tehnologiya modifikovanih budivelnih rozchiniv : Pidruchnik. Vidavnictvo KNUBiA, 2007.

[11] M.A. Sanickij, H.S. Sobol, T.Ye. Markiv, Modifikovani kompozicijni cementi: Navch. posibnik. Lviv: Vidavnictvo Lvivskoyi politehniki, 2010.

[12] I.G. Grankovsky, Strukturoobrazovanie v mineralnyh vyazhushih sistemah. Kiev: Naukova dumka, 1984.

[13] R. Kondo, M. Daimon, "Fazovyj sostav zatverdevshego cementnogo kamnya", Tez. dokl. VI mezhdun. kongr., 1976, kn. 1, pp. 35-48.

[14] P.A. Rebinder, Fiziko-himicheskaya mehanika - novaya oblast nauki. M.: Znanie, 1958.

[15] V.G. Batrakov, S.S. Kaprielov, F.M. Ivanov, A.V. Sheinfield, "Ocenka ultradispersnyh othodov metallurgicheskih proizvodstv kak dobavok v beton", Beton i zhelezobeton, no. 12, pp. 15-17, 1990.

[16] T.V. Lyashenko, S.V. Koval, Eksperimentalno-statisticheskoe modelirovanie i optimizaciya mnogokomponentnyh recepturno-tehnologicheskim sistem, Kiev: Znanie, 1990.

\title{
ОЦІНКА ВПЛИВУ МОДИФІКАТОРІВ І НАПОВНЮВАЧА НА РЕОЛОГІЧНІ І ФІЗИКО-МЕХАНІЧНІ ВЛАСТИВОСТІ ШТУКАТУРНИХ РОЗЧИНІВ
}

\author{
${ }^{1}$ Савченко С.В., к.т.н., доцент, \\ koval_s.v.@ukr.net, ORCID:0000-0002-4973-0552 \\ ${ }^{1}$ Антонюк Н.P., к.т.н., доцент, \\ antonuk_nr@ukr.net, ORCID: 0000-0003-1730-0723 \\ ${ }^{1}$ Бачинський В.В., к.т.н., с.н.с., \\ slawa_dk@ukr.net, ORCID: 0000-0003-2187-8616 \\ ${ }^{1}$ Одеська державна академій будівництва та архітектури \\ вул. Дідріхсона, 4, м. Одеса, 65029, Україна
}

\begin{abstract}
Анотація. Проаналізовано можливість використання мікрокремнезему в якості наповнювача для цементних штукатурних розчинів. В результаті аналізу літературних даних були визначені особливості гідратації цементу з мікрокремнеземом.

В експериментах досліджувалися реологічні характеристики цементних розчинів, що відрізняються вмістом аморфного кремнезему і питомою поверхнею.

Одним з найбільш важливих об'єктів вивчення впливу добавок мікрокремнезему та суперпластифікатору на властивості штукатурних розчинів була оптимізація за рахунок оптимального вибору концентрацій добавок реологічних властивостей сумішей і їх зв'язку 3 технологічними i експлуатаційними чинниками. Для аналізу i оптимізації кількісні співвідношення між показниками структури i властивостей штукатурних розчинів i визначальними їх чинниками рецептури i технології були отримані у вигляді експериментально-статистичних моделей, розрахованих з використанням системи СОМРЕХ.

За результатами вимірювань реологічних властивостей цементних розчинів, що містять мікрокремнезем з найбільшою питомою поверхнею і вмістом $\mathrm{SiO}_{2}$, побудовані повні
\end{abstract}

Bulletin of Odessa State Academy of Civil Engineering and Architecture, 2021, no. 82, page 105-113 
реологічні криві «швидкість деформації - напруга» i розраховані моделі основних реологічних показників. Для можливості регулювання властивостей цементних систем 3 суперпластифікатором в залежності від зернового і хімічного складу ультрадисперсного наповнювача були використані багатокомпонентні діаграми-тетраедри, які поєднувалися 3 концентраційним простором Дсп-Дмк в моделях «суміш - технологія - властивості».

Реалізовано спеціально синтезований насичений план 321 точок. Отримано моделі у вигляді наведених поліномів для різних властивостей цементно-піщаних розчинів (рухливість і міцність на стиск після 1, 3, 9, 28 і 81 діб тверднення в нормально-вологісних умовах). За допомогою узагальнюючого показника проведена оцінка чутливості системи до коливань фракційного складу і змісту $\mathrm{SiO}_{2}$.

Ключові слова: штукатурний розчин, мікрокремнезем, суперпластифікатор, реологічні властивості, міцність.

\title{
ОЦЕНКА ВЛИЯНИЯ МОДИФИКАТОРА И НАПОЛНИТЕЛЯ НА РЕОЛОГИЧЕСКИЕ И ФИЗИКО-МЕХАНИЧЕСКИЕ СВОЙСТВА ШТУКАТУРНЫХ РАСТВОРОВ
}

\author{
${ }^{1}$ Савченко С.В., к.т.н., доцент, \\ koval_s.v.@ukr.net, ORCID:0000-0002-4973-0552 \\ ${ }^{1}$ Антонюк Н.P., к.т.н., доцент, \\ antonuk_nr@ukr.net, ORCID: 0000-0003-1730-0723 \\ ${ }^{1}$ Бачинский В.В., к.т.н., с.н.с., \\ slawa_dk@ukr.net, ORCID: 0000-0003-2187-8616 \\ ${ }_{1}^{1}$ Одесская государственная академия строительства и архитектуры \\ ул. Дидрихсона, 4, г. Одесса, 65029, Украина
}

Аннотация. Проанализирована возможность использования микрокремнезема в качестве наполнителя для цементных штукатурных растворов. В результате анализа литературных данных были определены особенности гидратации цемента с микрокремнеземом.

В экспериментах исследовались реологические характеристики цементных растворов, содержащих микрокремнеземы, отличающихся содержанием аморфного кремнезема и удельной поверхностью.

Одним из наиболее важных объектов изучения влияния добавок микрокремнезема и суперпластификатора на свойства штукатурных растворов являлась оптимизация за счет оптимального выбора концентраций добавок реологических свойств смесей и их связи с технологическими и эксплуатационными факторами. Для анализа и оптимизации количественные соотношения между показателями структуры и свойств штукатурных растворов и определяющими их факторами рецептуры и технологии были получены в виде экспериментально-статистических моделей, рассчитанных с использованием системы СОМРЕХ.

По результатам измерений реологических свойств цементных растворов, содержащих микрокремнезем с наибольшей удельной поверхностью и содержанием $\mathrm{SiO}_{2}$, построены полные реологические кривые «скорость деформации - напряжение» и рассчитаны модели основных реологических показателей. Для возможности регулирования свойств цементных систем с суперпластификатором в зависимости от зернового и химического состава ультрадисперсного наполнителя были использованы многокомпонентные диаграммытетраэдры, которые совмещались с концентрационным пространством Дсп-Дмк в моделях «смесь - технология - свойства».

Реализован специально синтезированный насыщенный план из 21 точек. Получены модели в виде приведенных полиномов для разных свойств цементно-песчаных растворов (подвижность и прочность на сжатие после $1,3,9,28$ и 81 суток твердения в нормальновлажностных условиях). $\mathrm{C}$ помощью обобщающего показателя проведена оценка чувствительности системы к колебаниям фракционного состава и содержания $\mathrm{SiO}_{2}$.

Ключевые слова: штукатурный раствор, микрокремнезем, суперпластификатор, реологические свойства, прочность.

Стаття надійшла до редакції 8.01.2021 